\title{
原発性肝癌に関する研究 $(\mathrm{V}$ 報)
}

\section{選択的腹腔動脈造影による肝細胞癌の肉眼形態の診断}

\begin{tabular}{|c|c|c|c|c|c|}
\hline 陣内 & 重信 & 久保 & 保彦 & 森山 & 幹夫 \\
\hline 桑原 & 靖道 & 長崎 & 嘉和 & 下川 & 泰 ${ }^{*}$ \\
\hline & 和義 & 中島 & 敏郎** & 山 崎 & 武*** \\
\hline 中鴆 & 征男 & 奥田 & 邦雄 ${ }^{* * * *}$ & & \\
\hline
\end{tabular}

要 旨：診断の確実な盰細胞癌 141例の腹膯（肝）動脈造影フィルムについて検討した。内64例 では剖検又は手術によってフィルムと肉眼所見の対比を行った。 その結果，血管造影により癌の 肉眼型がかなりよく診断できる事がわかった，即ち単塊状型，被包型の䛦断は容易で，後者の被 膜は lucent な rim として認められる.大きい肝内動脈枝の偏位の無い例では型診断は必ずしも 容易ではないが，びまん型，偭結節変性は他の所見を参考にするとかなりの例で型馀断が可能で あった.あわせて肝細胞癌によくみられる所見，ことに特有な動・門脈 shunt および腫瘍栓塞を 反映する造影所見についても述べた。

索引用語 : 肝細胞癌 血管造影 腹腔動脈造影 原発性肝癌

\section{はじめに}

第 I 報において肝細胞癌の肉眼形態と臨床との関係を 考㦄した新しい肉眼分類（中島・奥田の分類）を提唱し だ。また第報に秃いてこれらの肉眼型がそれぞれ臨 床的特長を有する事を示した2゙。すすなわち肝細胞癌の肉 眼病理形態の違いは臨床経過, 予後にも反映され，こと に治療方針を考える上に型診断と，それに関保の深い非 癌部の肝硬変の有無・その程度の把握が必要である。 そ の目的に最る直接的な情報をむたらするのは肝スキャン と血管造影であるが，前者は癌の大きさを示すけれどす それから肉眼形態に関する情報は得られない。

我々は早くから腹胫動脈造影を肝細胞癌患者に施行し その訩断価值を強調してきたが，剖検後に摘出肝割面と の対比を行い得た症例が增えるにつれ，血管写の慎重な 判読から癌の肉眼形態かかがり正確に推定し得る事がか かった．即ち我々が今までに行った141例の肝細胞癌患 者の血管造影と，ことにその中で剖検後の対比を行い得

\footnotetext{
* 久留米大学第 2 内科 ****千萧大学第 1 外科

** 久留米大学第 1 病理 *****千菜大学第 1 内科 <受付日51年 5 月 14 日 $>$
}

た51例および手術によって切除肝と対比し得た 13 例につ いて検討した成績を示し，あわせて定型的な例について の対比を提示する。

\section{材料並びに方法}

久留米大学第 2 内科 降) および千葉大学第 1 内科および関連病院（1971年 7 月以降）に扎いて経験された診断の確実な肝細胞癌患者 で選択的腹腔動脈造影を行い得た 計141例のフィルム， 並びそその中で剖検し得た51例扰よび手街により肉腿病 理形態を詳細に娭討した13例の肉眼所見をフィルムと対 比した.

選択的腹胠動脈造影は Seldinger ${ }^{7)}$ および，Ödman ${ }^{8)}$ の方法により，予め先端を屈曲加工した KIFA 社製 green 又は red のカテーテルを guide wire を用いて䋊 皮的に股動脈より挿入した。造影剂は76\% Na-methylglucamine diatrizoate を用い $20 \sim 50 \mathrm{~m} l$ を Gidlund 自 動注入器により压は $2 \sim 5 \mathrm{~kg} / \mathrm{cm}^{2}$, 約 $10 \mathrm{ml} / \mathrm{sec}$ の速度で 注入，注入開始より0.5秒間隔，次いで 1 秒， 2 秒間隔 と延ばし計20枚を15〜24秒まで Elema Schönander 社製 連続摄影装置にて撮影した。又胃には予め発泡剤により 空気を入れコントラストをつけておいた。 
$30: 680$

肝

被

動脈走行の variation が多いので上腸間動脈造影る併 せて行い，又可能な範囲で肝動脈さらには固有肝動脈の 超選択的動脈造影を行った。な扰 cholangiocarcinoma の症例は今回は対象から除外した.

\section{成 績}

\section{I. 肝細胞演に共通に見られる所見}

肝の悪性腫湯の時にみられる血管造影上の諸変化中, 転移肝癌 と原発肝癌 とに共通にみられる変化むある が，特に動脈相の所見には肝細胞煰に特有なbのが多 $\left(^{9 \sim 12)}\right.$ 。次にその主なものを簡単に説明し，各肉眼型に おけるこれらの変化の有無, 頻度などから客锤的な診断 判定規準を設けんと試みた。

1) 尰瘍部位の hypervascularity，多くの例に扎いて 腫瘳内に小さな動脈が増加しており，動脈相の比較的早 期からそれが認められる、腫福発育に伴って新生された 細尰瘍血管 (neovasculature) と思われる.

2）太い腫湯血管．大きな腫湯には元からあった動脈 が太くなってをの中に流入するのみならず，太い不規則 な走行を示す動脈性の血管が認められる，その一部のる のは動脈相の初期から造影され乍ら後の相にかけて造影 剂が濃厚に残留し造影剤はゆるやかに移動して太い静 脈から直接連綄しているように見える。後者に対して 特定の㭔称はないようであるが，arteriovenous channel (Alfidi ${ }^{3)}$ ) 又は vascular channel と呼んですよいであろ 5 .

3）太い血管の偏位，王排，個々の腫㴼が大きくなら ないびまん型，多結節型，寡結節硬变型などでは，又腫 場自体が小さいらちはこの所見は認められない，塊状型 の大きいもので認められ，太い動脈が弧状に压排され
17 巻 9 号 (1976)

る.静脈相で肝内門脈枝が同じように王排されているの を諗める場合るある。

4）動脈壁浸蝕 (encasement). 太い動脈には稀にし か認められないが，3次分枝以下のむのではしばしば認 められる。切断む稀に諗められる。

5）肝内動・門脈経路 (A-P shunt). 半数以上の患者 において肝内の種々の大ささの門脈が動脈相の終り頃か ら造影され，動脈が消えた後にくっきり門脈枝だけが残 るよらにして認められる。形は正常の門脈枝と著しく翼 ってはいけない(A-P shunt かどうか疑わしい).又動脈 に平行して現われる太い不規則な陰影す同じ意味をむっ ている ${ }^{14)}$.これらは腫湯が門脈内に発青している間接の 証拋である．前の vascular channel と区別しなければ ならない，肝細胞癌に最む特有な所見である。

6）門脈这流.（5)と同じ現象であるが太い肝内門脈 枝内に腫堭栓塞があるとしばしば造影剂は肝内部を越え 門脈本幹内に逆流し，著しい場合には食道静脈瘤までる 造影し，その中に腫缩栓塞を filling defect として描出 する(1) . 太い肝内門脈に腫痬がつまっていると，その中

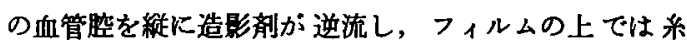
を束ねたよ5に見える所見を Okuda ${ }^{16)}$ が最初に thread and streaks sign として記載したが，同し意矮をるつ。

7）Vascular lake. 動脈相の後から造影剤が不規則な 形で㵿く腫瘍内に残瘤し，動かず，しかもなかなか消点

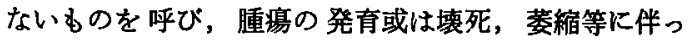
てできた，血液腔とつながって限局的に拉大した整に 造影剂が入り徐々に流れる現象と推定される。Kido は bud-like remnant of contrast material と表現した。 Puddling そいう表現はその淡いるのに相当する.

Table 1 Celiac angiographic characteristics of gross anatomical types of hepatocellular carcinoma as confirmed by autopsy or surgery

\begin{tabular}{|c|c|c|c|c|c|c|c|c|c|c|c|}
\hline $\begin{array}{l}\text { Gross } \\
\text { type }\end{array}$ & $\left\{\begin{array}{l}\text { No. of } \\
\text { cases }\end{array}\right.$ & $\begin{array}{l}\text { Hyper- } \\
\text { vascu- } \\
\text { larity }\end{array}$ & \begin{tabular}{|l} 
Arterial \\
tumor \\
vessels \\
\end{tabular} & \begin{tabular}{|l} 
Displaced \\
large \\
lessels \\
\end{tabular} & $\begin{array}{l}\text { Encase- } \\
\text { ment of } \\
\text { arteries }\end{array}$ & $\begin{array}{l}\text { Arterio- } \\
\text { portal } \\
\text { shunt }\end{array}$ & \begin{tabular}{|l|}
$\begin{array}{l}\text { Portal } \\
\text { regurgi- } \\
\text { tation }\end{array}$ \\
\end{tabular} & $\begin{array}{l}\text { Vascular } \\
\text { lake \& } \\
\text { channel } \\
\end{array}$ & $\begin{array}{l}\text { Tumor } \\
\text { blush }\end{array}$ & \begin{tabular}{|l|} 
Coronary \\
lucent \\
rim
\end{tabular} & $\begin{array}{l}\text { Diameter of } \\
\text { hep. artery } \\
\text { proper (min) }\end{array}$ \\
\hline I \& II & 6 & $6(100)$ & $4(67)$ & $2(33)$ & $1(17)$ & $3(50)$ & $1(17)$ & $1(17)$ & $6(100)$ & 0 & 7.9 \\
\hline III & 7 & $3(43)$ & $6(86)$ & $5(71)$ & $5(71)$ & $5(71)$ & 1 (14) & $5(71)$ & $5(71)$ & 1 (14) & 6.0 \\
\hline IV & 6 & $4(67)$ & 0 & $2(33)$ & $1(17)$ & 0 & 0 & & $5(83)$ & 0 & 5.5 \\
\hline $\mathrm{V}$ & 9 & $9(100)$ & $8(89)$ & $8(89)$ & $4(44)$ & $5(56)$ & 2 (22) & $9(100)$ & $9(100)$ & $6(67)$ & 7.0 \\
\hline $\mathrm{VI}$ & 13 & $13(100)$ & $11(85)$ & $11(85)$ & $9(69)$ & $9(69)$ & $4(31)$ & $10(77)$ & $13(100)$ & 0 & 7.2 \\
\hline VII & 15 & $15(100)$ & 11 (73) & $13(87)$ & $12(80)$ & $7(47)$ & $3(20)$ & $12(80)$ & $15(100)$ & 0 & 8.3 \\
\hline VIII & 8 & $8(100)$ & $4(50)$ & $4(50)$ & $6(75)$ & $6(75)$ & $3(38)$ & $4(50)$ & $8(100)$ & 0 & 7.2 \\
\hline Total & 64 & $58(91)$ & $44(69)$ & $45(70)$ & 38 (59) & $35(55)$ & $14(22)$ & $41(64)$ & $61(95)$ & 7 (11) & 7.2 \\
\hline
\end{tabular}

Number in $($ ) denotes percentage. 
8）Tumor Stain (blush). 造影剂が尰瘍部を毛細管相 から静脈相にかけて濃染する現象で, 尰湯部に造影郕が 多く入り（動脈依存のため),組織内に残っている所見で ある. 血液の drain が遅い事もこの所見に貢献するであ ろう.

これらの諸所見の認められる頻度を, 肝の肉眼所見と 対比して型をはっきり決め得た症例だけについて調へた 成績が Table 1 である.

\section{II. 肉眼所見と血管造影所見との対比}

中島, 奥田の肉眼分類では 8 つ型を設け，撤布型を 狭意のびまん型 (I ) と個々の結節が明瞭で人により結 節型と呼ぶものを細結節撤布型（II）に分けているが, 血管造影では両者を十分に鑑別する事はできない，した がって1つのカテゴリーとして撒布型として取扱った. 各型の特長は次のようである.

1）撤布型（分類 I , II )

肝は全体として中等度に増大し，肝内動脈枝の著明な 偏位はなく，走行むほぼ正常で, encasement むない。 太い動脈の新生はなく末梢において若干 hypervasular な感じがあり，毛細管相以後に小さい淡い腫瘍濃染像が 㕕範囲に認められる事が多い。

Fig. 1 にびまん型 (I ) の肝割面 (a) と同一患者の 生前の血管造影 $(b, c)$ を示す(50歳男子, 肝重量1550 $\mathrm{g}$, 組織分類 Edmondson-Steiner ${ }^{17)}$ のII 型)

Fig. 2 に右葉全体が細結節の撒布をみた例の血管造 影を示す左葉の原発栄は被包型, その周囲に漫潤した後 に肝内転移を示した例で小結節の撤布の血管造影の定 型的なむのである(49歳男子, 肝重量 $3200 \mathrm{~g}$, 組織分類 Edmondson-Steiner $の \mathbb{I} \sim \mathbb{I}$ 型).

2) 多結節型 (III)

明瞭な大小不同の結節がいくつか認められ，相互融合 していない状態のものをいら．本型では太い動脈の圧排 偏位はないが，第 3 分枝以下では圧非偏位を認め, その 附近は通常 hypervascular で，しばしば A-P shunt があ る. 棦脈相に和いて類円形の blush 又は pooling を認め る事が多い.

Fig. 3 に本型の 1 例を示す，右葉の第 3 分枝以下の 肝内動脈が不規則になり，その附近に比較的限局に neovasculature が認められ，毛細管相で不規則な濃染像 と末梢の門脈枝が造影されている（A-P shunt）（77歳 男子, 肝重量 $2600 \mathrm{~g}$, 組織分類 Edmondson-Steiner の II $\sim$ III).

3）宾結節硬変型 (IV)

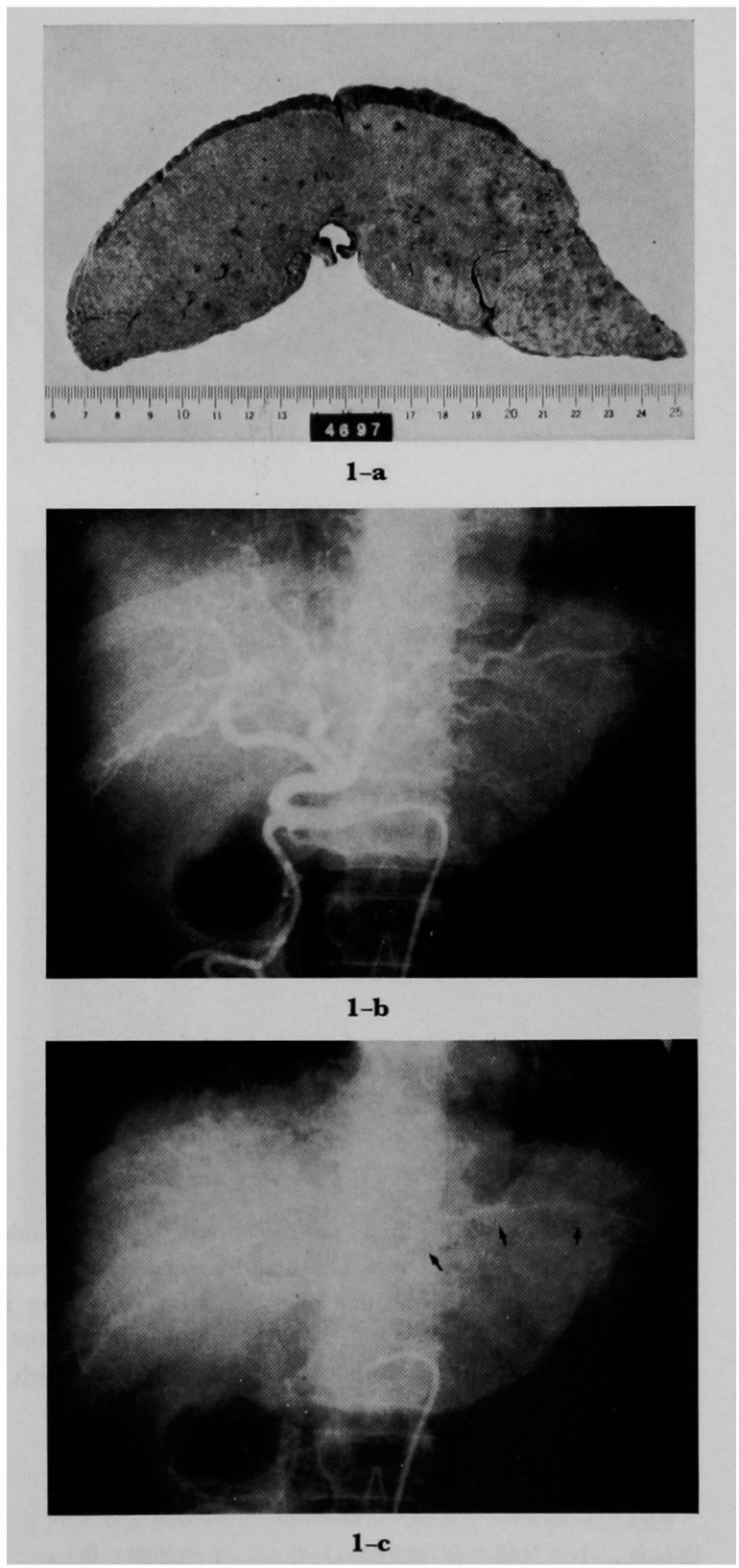

Fig. 1-a Liver with diffuse type hepatocellular carcinoma (HCC). Fine tumor nodules are scattered throughout the liver with thin stromal mesonodular cirrhosis. b. The hepatic artery proper and its branches are dilated and present a typical cirrhotic feature of winding, with some irregular neovascularization. c. Beside fine mottled blush throughout the liver, an arerior-portal shunt is obvious in the left lobe (arrows). 

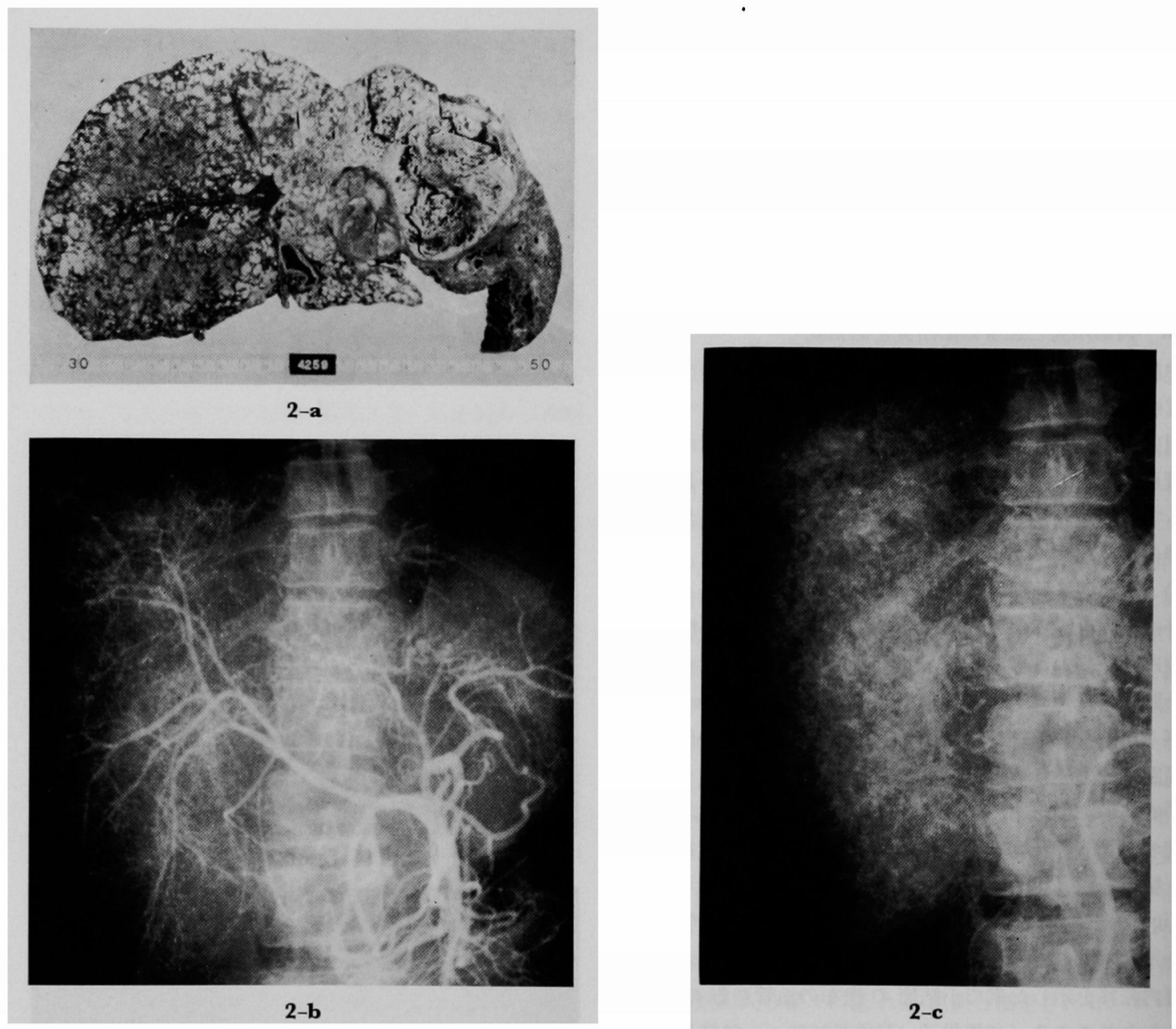

Fig. 2-a Two medium sized encapsulated HCC nodules are seen in the left lobe, and the right lobe is occupied by numerous fine nodules, secondary metastases from the left. b. The liver is enlarged and the right lobe has many fine neovascularization. There is no obvious localized displacement of large arteries. c. Multiple fine tumor stains are apparent in the right lobe. Only the right lobe is shown to demonstrate the typical fine nodular diffuse type, although this liver has two differing gross types.

本型は高度に萎縮した硬变肝の中に小さな肝細胞癌を 1 個ないし数個認める型で, 臨床的に肝硬変症として取 扱われ，小さな癌の存在は疑われながら生前証明し難い 例である. 血管造影は高度の肝硬変の変化そのるのであ るが，その中に小さな癌結節の変化を認めるか否か炕診 断の鍵がかかっている。

Fig. 4 に径 $1.5 \mathrm{~cm}$ の微小肝癌例とその結節に相当す る第 5 分枝動脈の変化が認められるが (矢印),この所見 は生前見落されていて，retrospective に明らかに巽常と 判定された（54歳男子，肝重量 $1140 \mathrm{~g}$, 日本住血吸虫症
に乙型肝硬変が合併したような型の肝䁍で，組織分類は Edmondson-Steiner $の$ I 型).

4) 被包型 (V)

割面で腫場は円く明瞭な硬い線維性被膜を被っている もので, 被膜自体は腫掦の幄くて, expansive な発育の表 現である. 主腫湯が大きくなるまでは肝内の離れた部位 に転移しない，即ち死亡時に主腫瘤が塊状を呈する場合 と，しからざる場合とあるが，一般に経過は長く AFP も比較的低值を示するのが多い。

血管造影の上で最す重要な所見は毛細管相以降におい、 


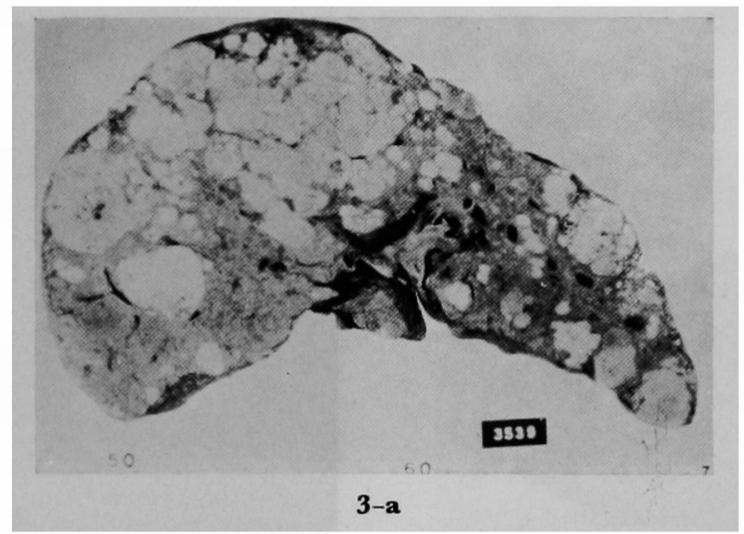

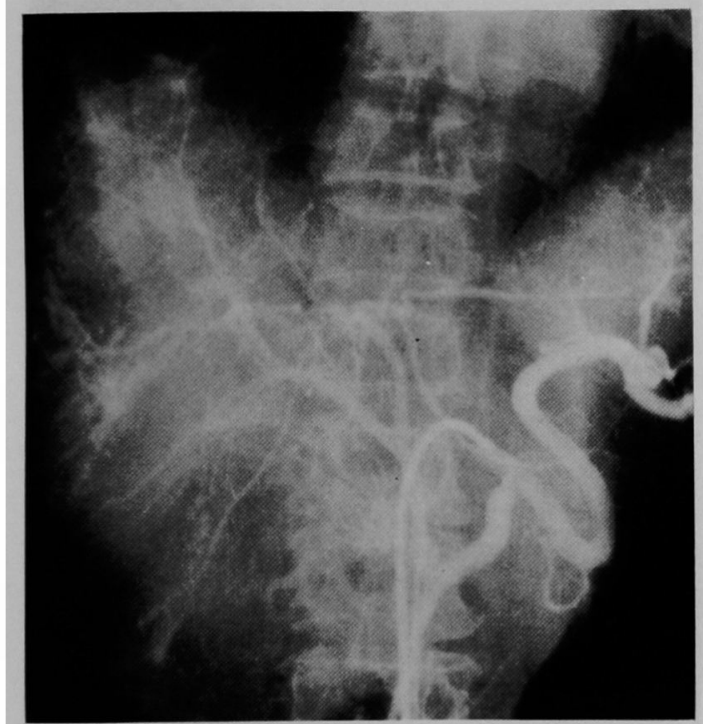

3-b

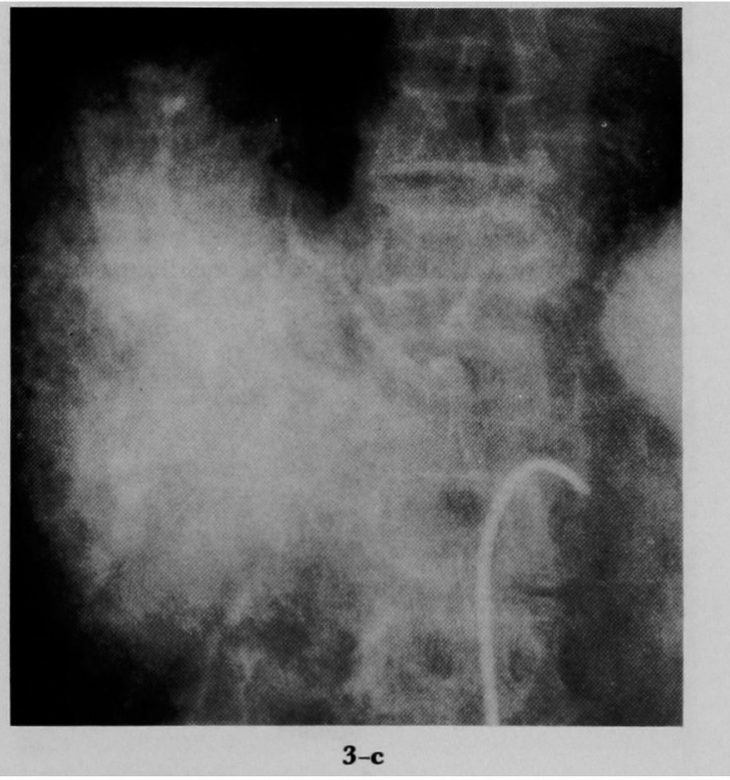

3-c

Fig. 3-a Multinodular HCC with various sized tumor nodules in a mildly cirrhotic liver. b. Arterial branches smaller than the 3 rd order are irregular with some neovascularization. c. Irregular tumor blush and opacification of portal branches (arterioportal shunts) are evident.

て厚い波膜が lucent な薄い rimとして証明されると いら事である．又一般に動脈性腫癋血管を含んで豊富な

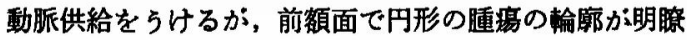
で，隀湯が大きいと元々の太い血管を弧状に圧排してい る.その場合太い血管は被膜の上にのっていて，浸強さ れていない。この点が後に述べる単塊状型との重要な鑑 別点である. 不規則にジグザグに走る血管は内部に隔壁 を生じているるのにしばしば認められ，その一部は被膜 表面のすのである。

Fig. 5 は右葉中央にでき左径 $7 \mathrm{~cm}$ の被包型肝細胞癌
で，内部にさらに隔譬を有し，一部出血壤死に陥ってい る. 新生動脈がかなり明らかで，中等度に hypervascular である. 静脈相 $(5-\mathrm{C})$ で肝静脈の出現および腫湯を 包んでいる矢印の lucent な薄い rim が明らかである. （53歳男子，肝重量 $1410 \mathrm{~g}$ ，組織分類 Edmondson-Steiner の II III)

Fig. 6 , 径 $7 \mathrm{~cm}$ の被包型細胞癌, 右肝のシンチの久 損を認めてから 3 年以上生存した症例であるが動脈相で 太い元々の動脈の弧状圧排が明瞭である（71藏男子，肝 重量 $3500 \mathrm{~g}$, Edmondson-Steiner 分類 I 〜 II 型, ビリル 


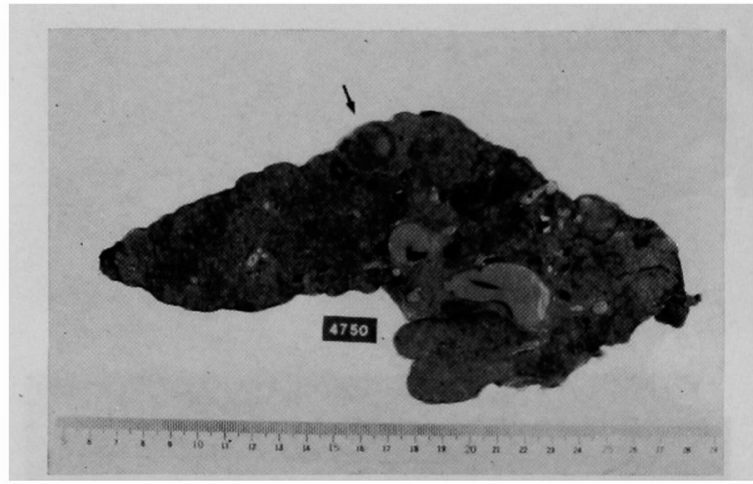

4-a

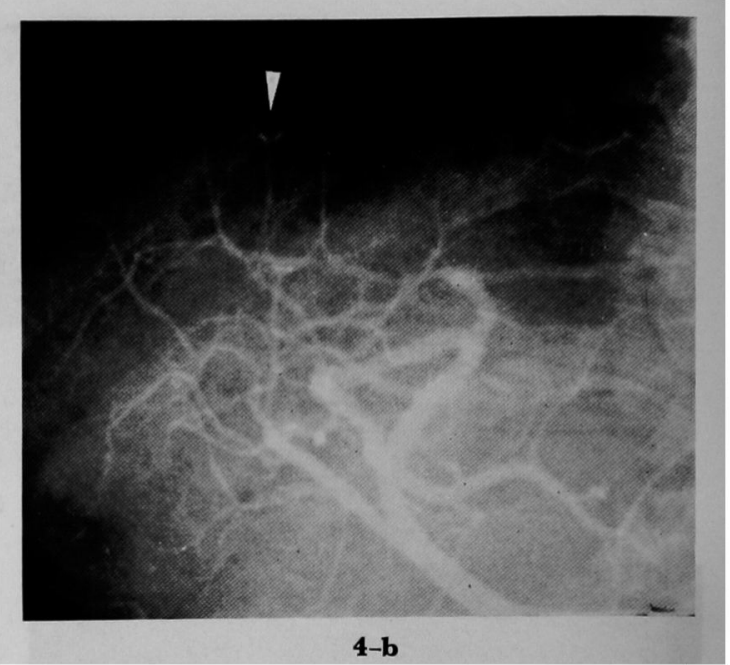

4-b

Fig. 4-a Markedly deformed liver with chronic schistosomiasis japonica. The right lobe is atrophied and the left hypertrophied. On the superior surface of the middle portion, a round $1.5 \mathrm{~cm}$ tumor nodule is seen (arrow) (cirrhotic oligonodular type). b. Celiac arteriogram demonstrating irregular arterial branches which assume a tree-branch pattern, markedly dilated lateral inferior branch of the left hepatic artery, and an abnormal, locally displaced and dilated artery of the 4 th order, which corresponds to the turnor (arrow).
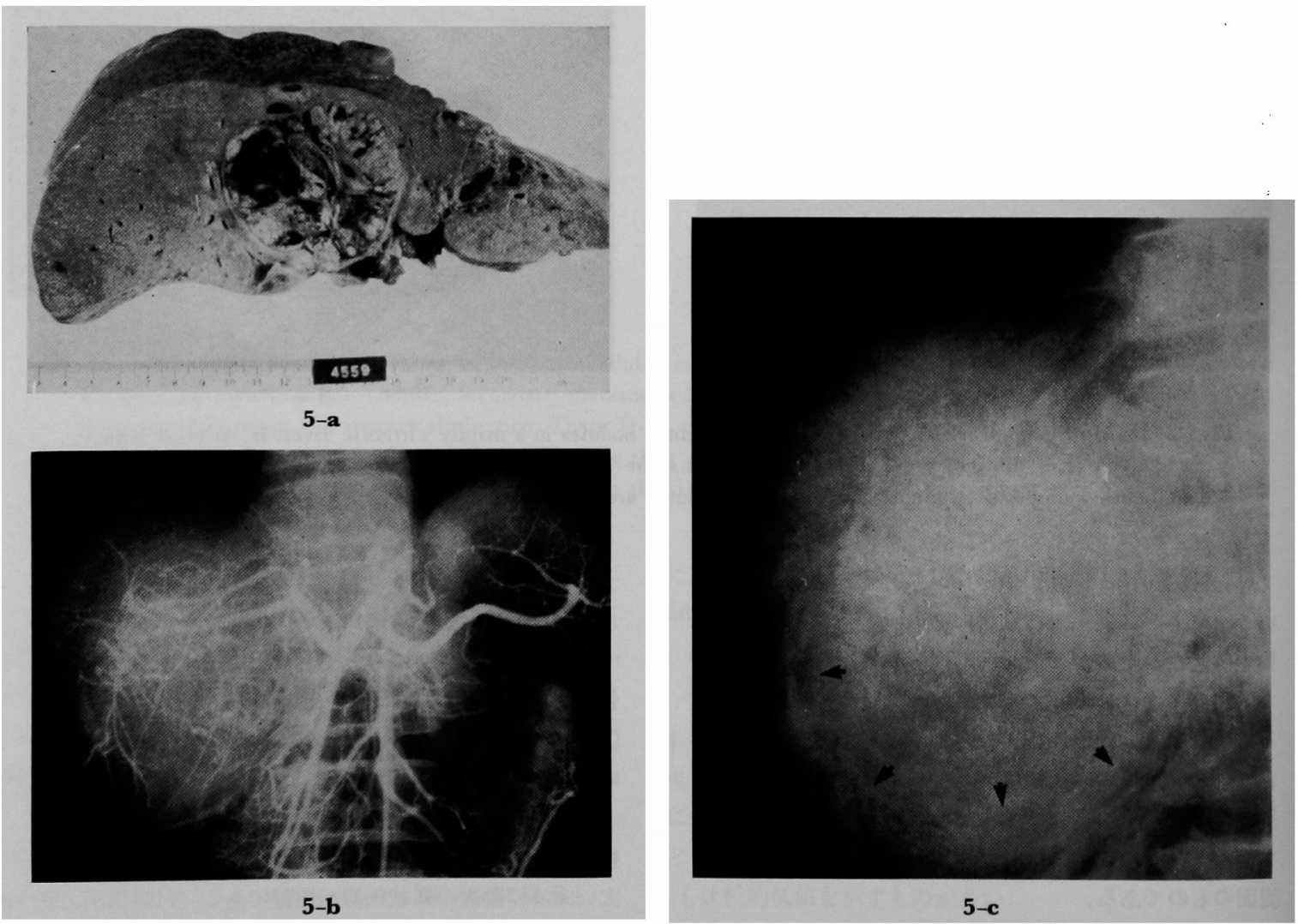

Fig.5-a An encapsulated type HCC. The tumor located in the center of the liver is surrounded by a thick fibrous capsule and its interior is partitioned by several fibrous septa. b. The arterial phase showing two feeding arteries and neovascularization in the center of the round tumor area. Displacement of the $2 \mathrm{nd}$ and 3 rd order arteries is apparent. c. The venous phase film showing the opacified right hepatic vein and the outline of the mass with a radiolucent rim (arrows). 


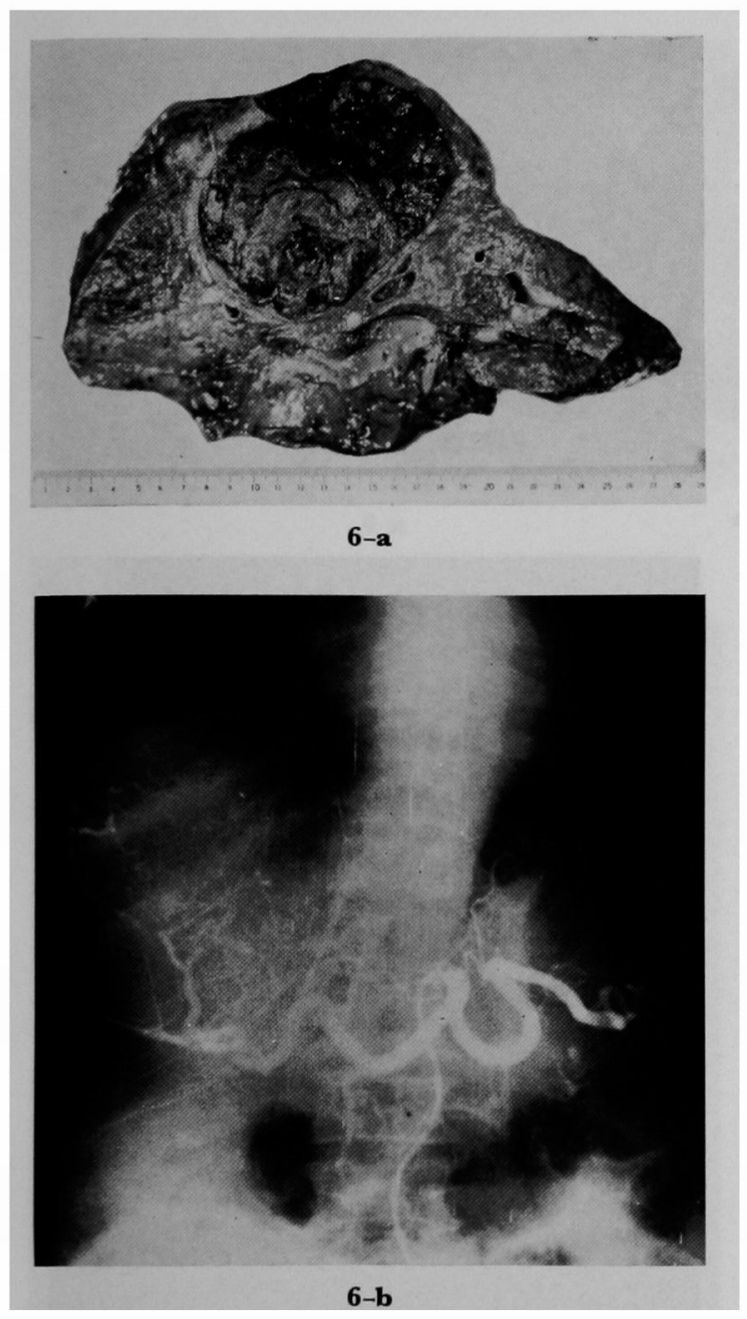

Fi5. 6-a Encapsulated, bilirubin producing HCC located in the right lobe superiorly. b. The arteriogram demonstrating marked displacement and stretching of the 1st and 2nd order arteries and irregularly coursing arteries forming secondary to the tumor (to the left of the mass). Tumor itself is only mildly hypervascular.

ビン産生を認めた).

5）結節塊状型 (V)

本型はいくつかの大きな結節が接近してその間の実質 が消失し，腫痬全体としては巨大になった型のもので， 進行した多結節型ょよび時により単塊状型で大きな娘栄 を生じたものとの区別が困難な事がある，血管造影上の 特長は 3 次分枝前後の比較的大きな動脈の偏位を認める

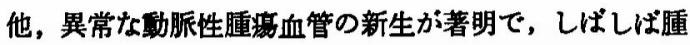

湟の門脈内発育に伴ら所見, 即ち A-P shunt および門脈 内造影剂逆流を認める。

Fig. 7 . 結節塊状型の肝 (a) とその動脈相 (b), および毛細管相（c）である。動脈相で著明な不規則の 腫場血管新生が認められるがその 輪遊は不規則で前の V型とは明らかに異なる。動脈相で 既に太い、vascular channel が現われており，それは次の相では太い channel として造影率を残して残っている. 肉眼的に内部の壊 死が認められる（30葴男子, 肝重量 $4870 \mathrm{~g}$, 組織分類 Edmondson-Steiner $の$ II 型).

6) 单塊状型 (VII)

1 つの腫湯が払大性 (expansive) 飞增大した, しかも 発育が速いので被膜を作らない型で非癌部は硬変性の変 化は一般に軽い，初めの5ちは主腫䉥は割面で円形（腫 瘤は球状）を呈しているが, 更に大きくなると一葉全体 を占拠し, 形も円形でなくなる. 早期診断, 切除の対象 となる、一般に hypervascular で, 円形ないし類円形の 腫瘤の输廍が分り，太い動脈が中に供給動脈となって流 入するようになるが, それを周辺に圧排する場合は動脈 は一部浸蝕された像を呈す. 後の相では tumor stain が 軽度ないし中等度に残る。

Fig. 8. 右葉全体が単一の巨大な腫瑒 とそれに隣接 してできた小娘巣によって置き変えられて括り肝内部に おいて太い閒脈の圧排が認められる．厚い被膜は認めら れない（a）.血管造影で太い動脈枝（右後上方枝）が著 明に圧排伸展しており，腫瘍は hypervascular である. 静脈相では lucent なrim（被膜）を認めない（28歳男 子, 肝重量 $4400 \mathrm{~g}$, 組織分類 Edmondson-Steiner II II 型).

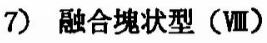

本型で尰瘍が 1 つの中心すって周辺に拡大したよ らな発育形成をとる V， VII型とは明らかに異り，腫場は 近接した実質内に浸潤性に不規則に払がり，間に短期間 残った肝実質は消失し 血管を含さグリソン氏鞘は圧排 されるのではなく腫凄の中に含まれてしまうょうにな る. 非癌部はしばしば肝硬変を欠き, 又は肝線維症程度 の変化にすぎない. 早期診断, 切除の最むよい対象とな る. 血管造影時には太い元々の 血管の排除, 王排はな く, 動脈が腫瘍内にとじ込められるので encasement と して認められる.太い血管の新生はなく，軽度ないし中 等度に hypervascular である. 後の相での blush はあっ ても大きなるのではない.門脈内腫焬発育所見をしばし ば認める. 


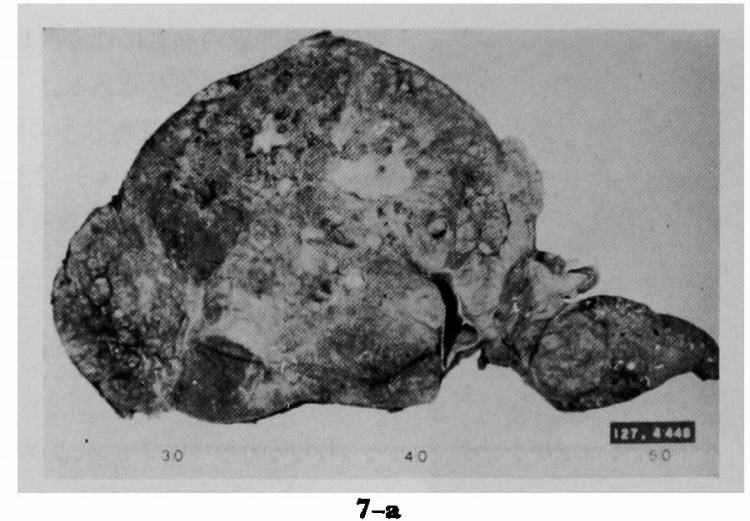

7-a

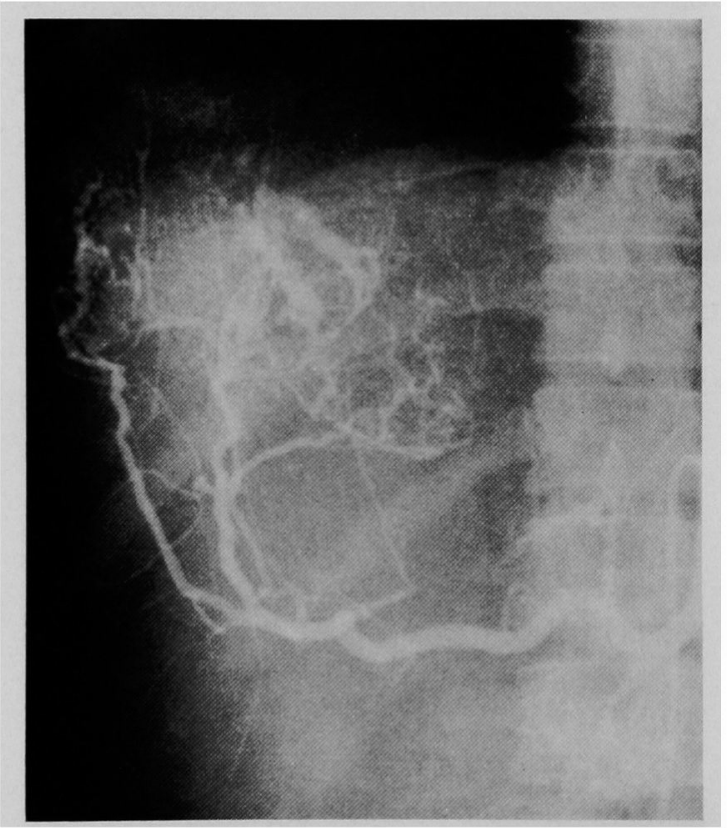

7-b

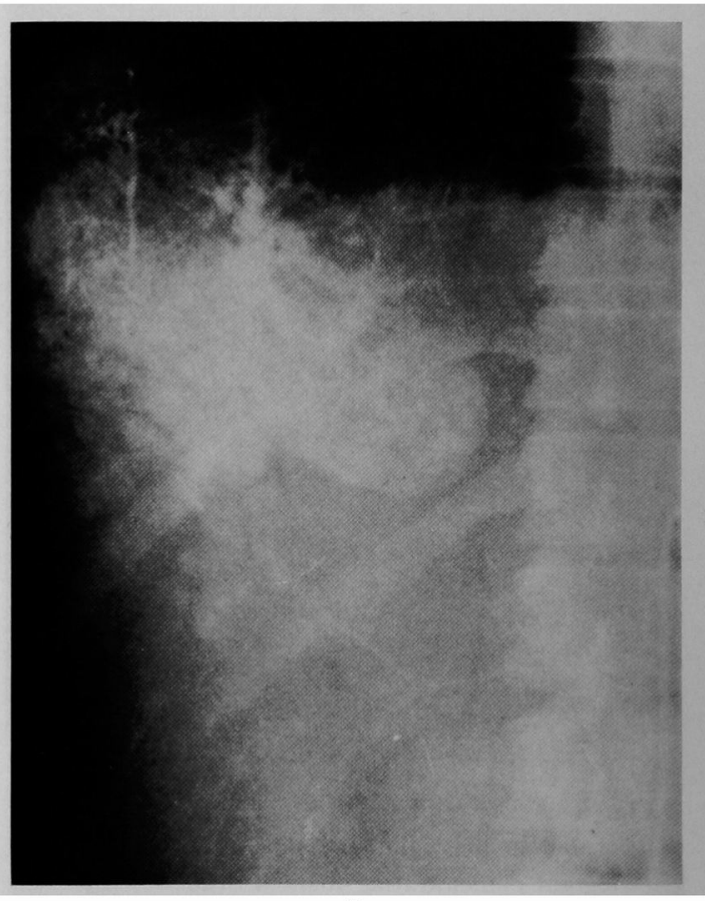

7-c

Fig. 7-a Liver bearing nodular massive type HCC. Sereval large, poorly bounded coalescing nodules are replacing most of the right lobe. b. The arteriogram demonstrating irregular arteries and bizarre vessels. Displacement of large arteries is not apparent. c. The outline of the tumor stain suggests a coalescent, but not solitary tumor. Irregular vascular channels still holding some contrast medium are apparent.

Fig. 9.切除した融合塊状型で，右葉の下半分位が 腫場で占められている．実質と腫場の境界はV， UII梨と 異なり弧状のきれいな割線を呈していない(a).動脈相 （b）で大きな血管の排除伸展はないか， 2 次分枝以下 の所で，動脈径がスムースに減して拈らず，即ち細い動 脈の encasement がある.血管新生を伴った小さい嗹場 結節が多発している感じが強い(54歳男子).

\section{III. 血管造影の所見による診断能と限界}

X線診断には経験が重要であり，個人差が甚々しい。 著者の中で特に経験の多い 2 名 (K.O と S.J) によっ て肉眼形態との対比を行った症例が増之肉眼型の診断に 関心をむち始めてから以後剖袷前の型診断が剖検時どの 位的中するかを調べたところ8〜9割の的中率であっ た. 又肉眼所見との対比が行之なかった Table 1 以外 


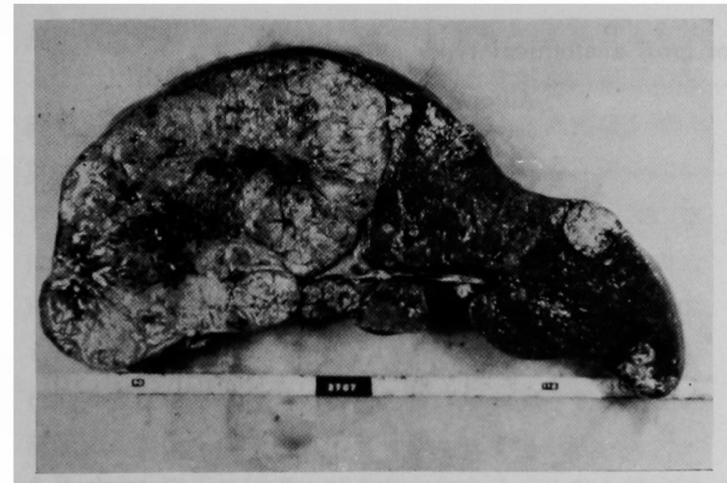

8-a

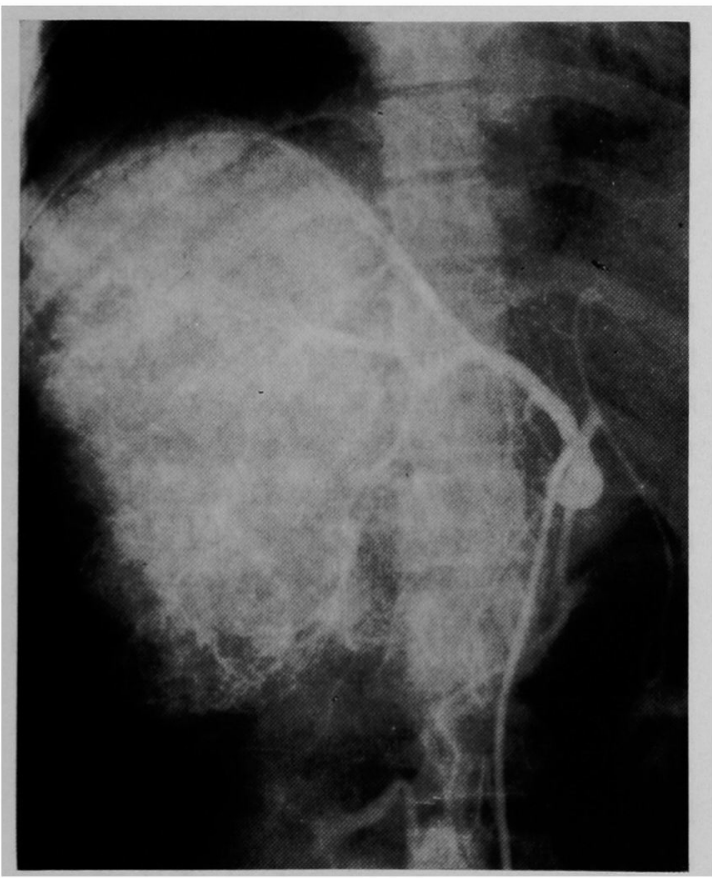

8-b

Fig. 8-a The righ lobe is replaced by a large solitary mass and a few smaller daughter tumor nodules that have coalesced from below. The main portal branches are displaced at the porta hepatis. No thick capsule is discerned grossly. b. The tumor is hypervascular, and there is marked stretching and displacement of the posterosuperior branch of the right hepatic artery. No radiolucent rim surrounding the mass was seen in the venous phase.
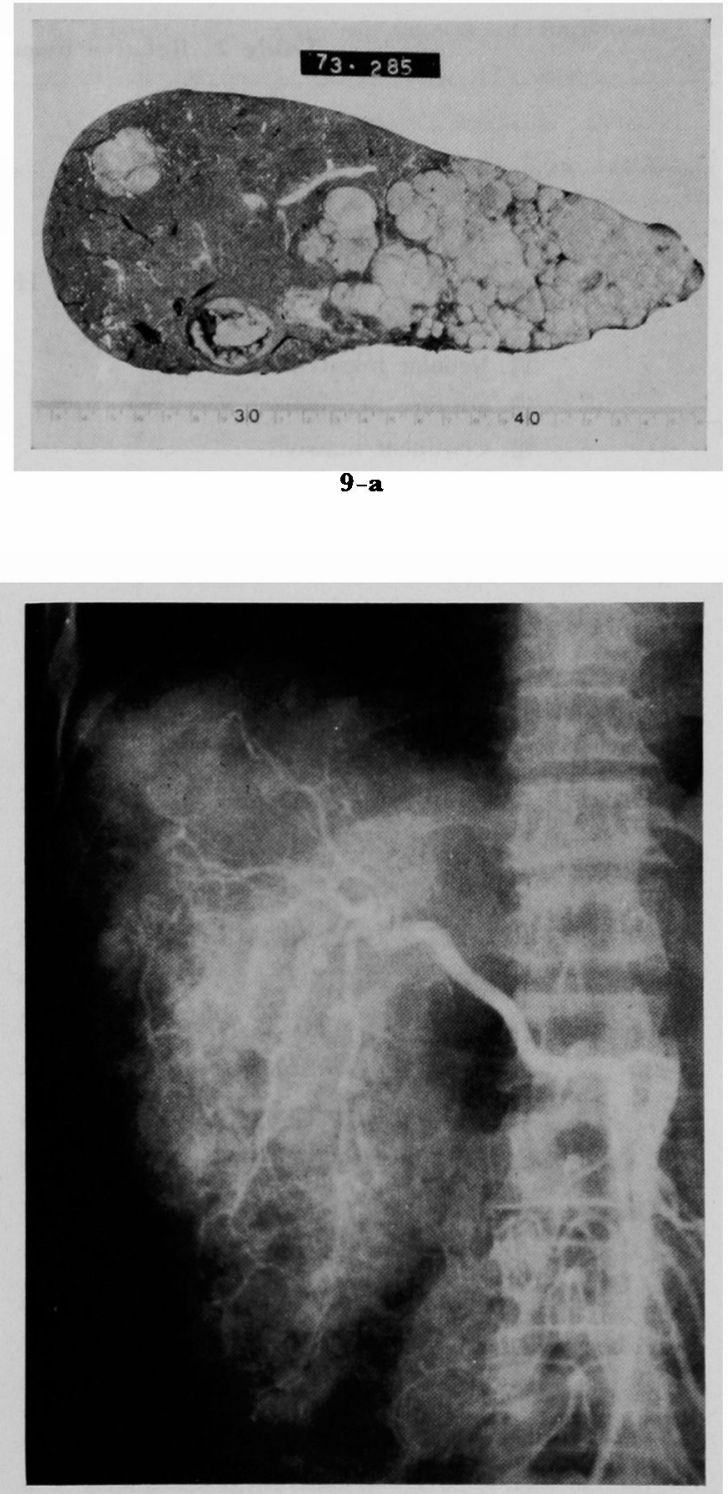

9-b

Fig. 9-a Resected right lobe demonstrating many confluent nodules of HCC in the lower portion (to the right), and encapsulated primary lesion (to the left below, internal bleeding) and a distant metastasis. Note that the original vessels are enclosed in the tumor, and are not displaced because the tumor is expanding in an infiltrative fashion instead of expansile growth. b. Late arterial phase showing multiple small hypervascular areas. The arteries are not displaced, but are encased at places. 
Table 2 Relative frequency of gross anatomical types

\begin{tabular}{lcc}
\hline \multicolumn{1}{c}{ Gross anatomical type } & $\begin{array}{c}\text { Autopsy and } \\
\text { surgery cases } \\
\text { (64 cases) }\end{array}$ & $\begin{array}{c}\text { All angiograms } \\
\text { incl. type unconfirmed } \\
\text { (141 cases) }\end{array}$ \\
\hline I \& II. Diffuse and fine nodular diffuse & $9.4 \%$ & $7.1 \%$ \\
III. Multinodular & 10.9 & 13.5 \\
IV. Cirrhotic oligonodular (incl. minute HCC) & 9.4 & 8.5 \\
V. Encapsulated & 14.1 & 13.5 \\
V. Nodular massive & 20.3 & 20.6 \\
VII. Solitary massive & 23.4 & 22.7 \\
VII. Confluent massive & 12.5 & 14.2 \\
\hline
\end{tabular}

の残りのフィルムについて 2 人で別タに診断して喰違い を調べると，その違いは剖検診断と合わなかった型と大 体同じで，それは主として多結節型と結節塊状型と融合 塊状型の 3 者の鑑別の誤り又は意見の差であった。しか し融合塊状型は結節塊状型よりも vascularity が低い点 が鑑别上重要で，又肝全体が大きく非癌部の肝硬变所見 が弱い点が多結節型との鑑別点となる．肝シンチ所見を 参考にするとこれらの鑑別がより正しく行える. 即ち欠 損部がはっきりと大きければ多結節型よりる結節塊状型 らしいといら事になる。被膜がはっきり lucent の rim として現われない被包型と単塊状型との鑑別は時々難 しいがそのどららかであるといら判定は誤る事はなか った. 明瞭な小班点状の tumor stain を示さないびまん 型は AFP がはっきり陽性で組織診断むついている症例 ではないと血管造影から詮断する事は困難で，やはりシ ンチではっきりした defect が無い所見等を参考に疑診 をつける程度に留まる．時に細結節撒布型と融合塊状型 の鑑別が難しい場合すあった．上記の 8 分類型はあくま で定型的な型を示したもので，中に2 型の中間の上らな あの，あるい俩方の性質をるつような例もあり（例之 ば Fig. 2 の例)，後者では優位な肉眼型の診断をする 事になる。稀に転移肝癌との 区別が難しい例があった が，転移肝癌は多発性で肝硬变所見を伴わない等の他の 所見を参考にすれば多くは爁別が可能である。

究極的にシンチなどを参考にして 2 人でつけた型分類 を Table 2 に示し, 各型の相対的な頻度を手術および 剖検材料における相対的頻度と対比してみると, 両者が 著しく異っていない事がわかる。

\section{考按}

既に述べたよらにX線による診断というるのは読影者 の経験と病理学的裹付けのあるフィルムを見た数などに
大きく依存する．肝細胞癌の血管造影も例外でなく，そ れを多数見た尃門家は定型的なフィルムを見ると一目で 診断をつけるが，他の者にはそれができない。いわゆる 専門家がどの程度の診断をつけらるかという事になる と、たたこれは「肝癌た」「原発肝癌だ」ヒョランギオー ムでなくて「メハトーマだ」といら猃断だけでは不十分 である. 第且報で報告したように各肉眼型それそれれ踩 床像，㹩過に差があり，治療方針ことに積極的な手術に 踏又切るかどらか，化学療法を行らかどらかを正しく判 断しないとかえって予後を悪く寸る，その上らな意味か らも血管造影により肉眼型を判断できれば極めて有意義 である.シンチグラムとの対比から診断能が向上する事 は当然であり，両者の対比を強調する報告むあるが, 又 それぞれ単独による肝癌の診断能では血管造影が優れる としているが・帛，これは癌の有無の崄断能についてであ り，我々が強調するのは更に一歩進んだ癌の形態診断に あシンチが鑑別お゙よ゙裏付け診断に役立つという事であ る. Gammils $^{19)}$ は手術の適応を決める 上で腫瘍の位着 断，ことに両葉に变化のある撒布型，多結節型は血管 造影で診断除外できるとしているが，考方方は同じであ る．手術を前提とする場合は非癌部の方をむしろ十分精 査する必要があり, 癌のある側の肝葉の精査を儀牲にす る必要起る。

肝細胞癌と cholangiocarcinoma との血管造影上の鑑 別は後者が hypovascular であり ${ }^{20,21)}$, A-P shunt が無い という点以外に確実な区別点はない，実際には，AFP が後者で通常陰性である事, 黄疸出現㑯向が強いといら ような他の所見を参考にして鑑別しているが，混合型 になるとこれは肝細胞癌に準じて取扱われるべきであ り，区別は極めて困難である、肝細胞癌で組織型により hypovascular な型をとるものもあり ${ }^{22)}$ ，血管造影上の 
差を滛の組蟣学的特長と結びつけようとする試みすあ $ろ^{12,23)}$. 我々の見解は癌の組織学的な性質が肉眼型の基 礎であり，血管造影上の特長は直接には主に肉眼形態の 反映であり，間接に組織学的性質と関係あると考兄てい る.しかし，vascularityは組織学的所見と関保が深い事 は事実である.なお A-P shunt は肝細胞に極めて特有な 所見で璂結節硬変型を除く各肉眼型で認められるが中で る進行した塊状型で高頻度に認められる。しかし稀に肝 細胞の強度な再生現象に伴って諮められたり ${ }^{201}$ ，門脈大 静脈吻合法後 ${ }^{25\rangle}$ にす認められる事が報告されているが， A-P shunt 附近に腫場血管所見を欠くところから鑑別は 可能である.

\section{むすひ}

診断の確実な肝細胞癌症例で選択的腹胿動脈（又は肝 動脈) 撮影を行い，判読に耐える 造影像が得られた141 例のフィルムおよびその中で剖検又は手術により肝の肉 眼所見と対比し得た64症例について検討した。その結 果，血管造影はかなりよく窑の肉眼形態を反映する事， すなわち肝細胞癌の肉眼形態診断に血管造影が極めて有 用である事を明らかにした。単発性で塊状型に増大する 型, 被膜を有する型は診断が可能で，ことに後者の厚い

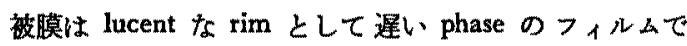
判読できる事を示した．太い肝内動脈の偏位のない型で は，こまかい診断は必ずしる容易でないが，びまん型や 硬変の強い肝に合併する小さい数の少ない腫湟の型すか なり正確に䇏断し得た。併せて肝細跑癌に上く見られる 血管造影上の変化，および特有な変化即ち動門脈シャン トおよび門脈内尰湯塞栓についても言及した。

\section{文 献}

1) 中島敏郎, 神代正道, 他 : 原発性肝癌に関する 研究，第 1 報，原発性肝細胞の新しい肉眼分 類, 肝葴. $15: 279,1974$.

2）下川 泰, 久保保彦, 他 : 原発性肝癌に関する 研究, 第 3 報, 肝細胞癌の中島・奥田分類とそ の䧗床病理学的特徽, 肝炡. $16: 752,1975$.

3) 奥田邦雄, 森山幹夫, 他 : 肝疾患と $\mathrm{X}$ 線検查 （12）選択的動脈造影による肝满癌の診断，綜 合臨床. $20: 1817,1971$.

4) 奥田邦雄，欶山幹夫，他：肝疾患 とX 線検査 （13）人パーマの血管造影所見，綜合臨床. $20: 1991,1971$.

5) 奥田邦雄, 下川 泰, 他 : 肝癌診断の現況, 臨 床外科, $28: 323,1973$.
6) Okuda, K.: Clinical aspects of hepatocellular carcinoma-analisis of 134 cases. In: Hepatocellular Carcinoma. Okuda, K., Peters, R.L. Eds., John Wiley, New York, 1976 (in press).

7) Seldinger, S.I.: Catheter replacement of needle in percutaneous arteriography. Acta Radiol. 39: 368, 1953.

8) Odman,: Percutaneous selective angiography of the coeliac artery. Acta Radiol. Suppl., 159, 1958.

9) Boijsen, E. and Abrams, H.L.: Roentgenologic diagnosis of primary carcinoma of the liver. Acta Radiol. Diag., 3: 257, 1965.

10) Yu, C.: Primary carcinoma of the liver (hepatoma). Its diagnosis by selective celiac arteriography. Am. J. Roentgen., 99: 142, 1967.

11) Nebesar, R.A. \& Pollard, J. et al.: Angiographic diagnosis of malignant diseases of the liver. Radiology, 86: 284, 1968.

12) Kido, C. \& Sasaki, T. et al.: Angiography of primary liver cancer. Am. J. Roentgen., 113: $70,1971$.

13) Alfidi, B.J. \& Rastogi, H. et al.: Hepatic arteriography. Radiology, 90: 1136, 1968.

14) Okuda, K. \& Musha, H. et al.: Angiographic demonstration of intrahepatic arterio-portal anastomoses in hepatocellular carcinoma. Radiology (in press).

15) Okuda, K. \& Moriyama, M. et al.: Roentgenologic demonstration of spontaneous reversal of portal blood flow in cirrhosis and primary carcinoma of the liver. Am. J. Roentgen., 119: $419,1973$.

16) Okuda, K. \& Musha, H. et al.: Demonstration of growing casts of hepatocellular carcinoma in the portal vein by celiac angiogra phy: the thread and straks sign. Radiology, 117: 303, 1975.

17) Edmondson, H.A. \& Steiner, P.E.: Primary carcinoma of the liver. A study of 100 cases among 48,900 necropsies. Cancer, 7: 462, 
1954.

18) Rossi, P. \& Gould, H.R.: Angiography and scanning in liver disease. Radiology, 96: 553, 1970.

19) Gammil, S.L. \& Takahashi, M. et al.: Hepatic angiography in the selection of patients with hepatomas for hepatic lobectomy. Radiology, 101: 549, 1971.

20) Kaude, R. \& Rian, R.: Cholangiocarcinoma. Radiology, 100: 573, 1971.

21) Okuda, K. \& Iio, M.: Radiological Aspects of the Liver and Biliary Tract. Igaku Shoin, Tokyo, 1976, p. 307-312.

22) Reuter, S. R. \& Redman, H.C. et al.: The spectrum of angiographic findings in hepatoma. Radiology, 94: 89, 1970.

23）木戸長一郎 : 覀性腫瘍のレントゲン図譜，原発 性肝がん，綜合臨床， $25: 269 ， 1976$.

24) Farrel, R. \& Steinman, A. et al.: Arteriovenous shunting in a regenerating liver simutating hepatoma. Report of a case. Radiology, 102: 279, 1972.

25) Bookstein, J. \& Boijsen, E. et al.: Angiography after end-to-side portacaval shunt. Clinical, Laboratory, and pharmacoangiographic observations. Invest. Radiol., 6: 101, 1971 .

\title{
Studies on Primary Liver Carcinoma. V. Diagnosis of Gross Anatomical Types by Celiac Angiography
}

\author{
Shigenobu Jinnouchi, Yasuhiko Kubo, Yutaka Shimokawa, Mikio Moriyama, \\ Seido Kuwahara, Yoshikazu Nagasaki*, Kazuyoshi Sakamoo, \\ Toshiro Nakashima**, Takeshi Yamazaki***, \\ Yukio NakajIma and Kunio OKudA****
}

Celiac (hepatic) angiograms of good quality obtained in [4] cases of hepatocellular carcinoma with uneqivocal diagnosis were analyzed, of which comparison of angiograms with the gross anatomical feature on the cut-surface of the liver was possible in 64 either autopsy or resection. It was found that the angiograms reflect the gross anatomical findings fairily well, and particulary, the solitary massive type and encapsulated type were readily diagnosed. A thick fibrous capsule in the latter type was discerned as a radiolucent rim in the late phase angiograms.

In patients in whom no displacement of large intrahepatic arteries accurate diagnosis of gross types was not always easy, but some of the diffuse and the cirrhotic oligonodular type were diagnosed with certain accuracy. The typical angiographic alterations of hepatocellular carcinoma and pathognomic changes such as arterio-portal shunts and tumor thrombus associated findings are also discussed.

* 2nd Department of Medicine, Kurume University School of Medicine, Kurume

** Ist Department of Pathology, Kurume University School of Medicine, Kurume

*** 1st Department of Surgery, Chiba University School of Medicine, Chiba

**** 1st Department of Medicine, Chiba University School of Medicine, Chiba 